\title{
CHANGES IN SPECIFIC LOADS OF MINERAL COMPONENTS OUTFLOWING FROM CATCHMENT AREA OF RIVER SUPRAŚL IN 2001-2009
}

\author{
Mirosław Skorbiłowicz' ${ }^{1}$ Piotr Ofman ${ }^{1}$ \\ 1 Białystok University of Technology, Wiejska 45A, 15-351 Białystok, Poland, e-mail: m.skorbilowicz@pb.edu.pl
}

Received: 2014.08 .12

Accepted: 2014.10.17

Published: 2015.01.02

\begin{abstract}
The purpose of this paper was to determine changes in loads of $\mathrm{N}_{-} \mathrm{NH}_{4}^{+}, \mathrm{S}_{-} \mathrm{SO}_{4}^{2}$, $\mathrm{P}_{-} \mathrm{PO}_{4}^{3-}, \mathrm{N}-\mathrm{NO}_{3}^{-}, \mathrm{P}_{\mathrm{og}}, \mathrm{Cl}^{-}, \mathrm{Ca}^{2+}, \mathrm{Mg}^{2+}$, and their origin in waters outflowing from Supraśl catchment. Research was carried out in the period from 2001 to 2009 in three measurement points located around Gródek, Nowodworce and Dzikie. Obtained values of specific load were raging for: $\mathrm{N}_{-} \mathrm{NH}_{4}^{+} 0.051 \div 2.094 \mathrm{~kg} \mathrm{~N}-\mathrm{NH}_{4}^{+} \cdot$ ha $^{-1}$. year ${ }^{-1}$, $\mathrm{S}_{-} \mathrm{SO}_{4}{ }^{2-} 16.50 \div 30.00 \mathrm{~kg} \mathrm{~S}-\mathrm{SO}_{4}{ }^{2-\cdot}$ ha $^{-1} \cdot$ year $^{-1}, \mathrm{P}^{4} \mathrm{PO}_{4}{ }^{3-} 0.17 \div 0.45 \mathrm{~kg} \mathrm{P}-\mathrm{PO}_{4}{ }^{3 \cdot} \cdot$ ha $^{-1} \cdot$ year $^{-1}$, $\mathrm{P}_{\text {og }} 0.44 \div 0.78 \mathrm{~kg} \mathrm{P} \cdot \mathrm{ha}^{-1} \cdot$ year $^{-1}, \mathrm{Cl}^{-1} 14.58 \div 26.80 \mathrm{~kg} \mathrm{Cl}^{-} \cdot \mathrm{ha}^{-1} \cdot$ year $^{-1}, \mathrm{Ca}^{2+} 68.2 \div 77.1 \mathrm{~kg}$ $\mathrm{Ca}^{2+\cdot} \mathrm{ha}^{-1}$.year ${ }^{-1}, \mathrm{Mg}^{2+} 9.57 \div 12.29 \mathrm{~kg} \mathrm{Mg}^{2+} \cdot \mathrm{ha}^{-1} \cdot \mathrm{year}^{-1}$. In addition, linear Pearson correlation coefficients were calculated between specific loads of individual components and fertilization form in each measuring point. There were obtained statistically significant correlations between NPK fertilization and specific loads of $\mathrm{N}_{-} \mathrm{NH}_{4}^{+}, \mathrm{P}_{\mathrm{og}}, \mathrm{Cl}^{-}$, $\mathrm{Ca}^{2+} \mathrm{i} \mathrm{Mg}^{2+}$ and between manure fertilization and $\mathrm{S}_{-} \mathrm{SO}_{4}^{2-}, \mathrm{Ca}^{2+} \mathrm{i} \mathrm{Mg}^{2+}$.
\end{abstract}

Keywords: catchment, fertilization, mineral components.

\section{INTRODUCTION}

Mineral components outflow to catchments surface waters depend on topography, soils type and their conciseness, their ability to buffer and sorption, vegetation, water and climatic conditions and in particular precipitation and anthropogenic factors, which include: land reclamation, agricultural production intensity and presence of settlements and farming facilities in catchment area [Szpakowska and ŻyczyńskaBałoniak 1992; Sapek 1996b; Koc et al. 1999; Miller et al. 2001; Spychaj-Fabisiak et al. 2001; Koc et al. 2002a; Koc and Szymczyk 2003; Koc et al. 2003; Szymczyk and Cymes 2004; Kuźniar et al. 2008].

Studies carried out by Skorbiłowicz [2004] in selected river catchments of upper Narew showed that waters flowing through the land used for agriculture purposes had higher concentration of calcium and magnesium ions than waters flowing through forested catchments. On the other hand, water from forested areas is richer in iron and manganese ions in compare to water from agri- cultural catchments. The reason of increased nutrients' migration into rivers are changes in land use, especially deforestation, afforestation, and drainage of wetlands and peat bogs.

In order to determine agricultural impact on water chemical composition in catchments average values of components concentrations are used in natural waters. Component concentration mean values in water is taken as a measure of chemical composition assessment in water. Specific load seems to be a better factor as allows the assessment of the examined components and specification of their impact in catchment water quality, and in particular their migration the outside catchment. This allows to determine the part of non-point sources of pollution in river or water reservoir [Hansen et al. 2000; Pulikowski et al. 2001; Pulikowski 2004]. Specific loads of substances are a product of average concentration and average flow in micro-catchment [Miler and Murat-Błażejewska 1997].

The aim of this study was to assess trends in specific loads of minerals eluted from Supraśl catchment area and to determinate their origin. 


\section{METHODOLOGY}

For changes assessment in specific loads of individual components results from Supraśl river (concentration) were used from the research carried out under the State Environmental Monitoring by the Regional Inspectorate of Environmental Protection in Białystok in period from 2001 to 2009. Water samples were collected from three measurement points located on river Supraśl. The first measurement point (PP1) was located near the Gródek, the second (PP2) in Nowodworce and third (PP3) near Dzikie (Figure 1). The concentration of each component was analyzed in accordance with the following Research Procedures and Polish Standards:

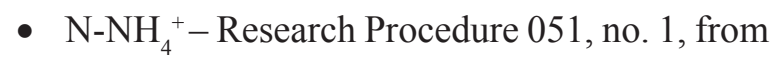
07.12.2009

- $\mathrm{S}_{-} \mathrm{SO}_{4}{ }^{2-}-\mathrm{PN}-\mathrm{ISO}$ 9280:2002

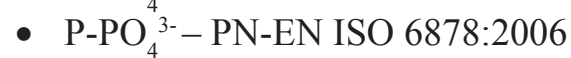

- $\mathrm{N}^{-N^{2}}{ }^{-}-\mathrm{PN}-\mathrm{EN}$ 26777:1999

- Total phosphorus - PN-EN ISO 6878: 2006

- $\mathrm{Cl}^{-}-\mathrm{PN}-\mathrm{ISO}$ 9297:1994

- $\mathrm{Ca}^{2+}-$ PN-ISO 9964-1:1997

- $\mathrm{Mg}^{2+}-$ PN-ISO 9964-2:1997

Specific loads of individual components were calculated according to the following equation [Skorbiłowicz 2010]:

$$
\phi_{\mathrm{rz}}=\frac{\mathrm{c} \cdot \mathrm{q}}{\mathrm{F}}
$$

where: $\phi_{\mathrm{rz}}-$ component specific load entered form catchment in $\mathrm{kg} \cdot \mathrm{ha}^{-1} \cdot \mathrm{year}^{-1}$,

c - component average annual concentration in $\mathrm{kg} \cdot \mathrm{m}^{-3}$,

$\mathrm{q}$ - average annual water flow in measurement point in $\mathrm{m}^{3} \cdot \mathrm{s}^{-1}$,

$\mathrm{F}$ - catchment area in ha.
Catchment area, average annual water flow and structure of soil usage were adopted in accordance with the data presented by Skorbiłowicz [2010].

Table 1. Catchment area and characteristic water flow [Skorbiłowicz 2010]

\begin{tabular}{|c|c|c|}
\hline $\begin{array}{c}\text { Point } \\
\text { number }\end{array}$ & $\begin{array}{c}\text { Catchment area } \\
{[\mathrm{ha}]}\end{array}$ & $\begin{array}{c}\text { Average water flow } \\
{\left[\mathrm{m}^{3} \cdot \mathrm{s}^{-1}\right]}\end{array}$ \\
\hline PP1 & 97000 & 0.67 \\
\hline PP2 & 152300 & 5.36 \\
\hline PP3 & 193200 & 10.13 \\
\hline
\end{tabular}

In this study Pearson correlation coefficients were calculated using a licensed software version of Statistica 10. For statistical analysis, the data from Supraśl catchment (Table 2), and data on the usage of mineral and organic fertilizers was used (Table 3 ). For specific loads trends calculation the average loads from three measurement points for each year were used. Linear changes trends and mathematical models were performed using Excel 2013.

Supraśl catchment belongs to a group of agricultural catchments. Area used for agricultural purposes is equal to $67 \%$, forest covers $30 \%$ and urban area is equal to $3 \%$ of total catchment area.

According to GUS data (Table 3), the usage of NPK (mineral) fertilizers in Podlaskie did not change significantly in the period from 2001 to 2009 , however, a small upward trend was noted. In the period from 2001 to 2005 average lime fertilizer usage was equal to $58.8 \mathrm{~kg} \cdot \mathrm{ha}^{-1}$. Beginning

Table 2. Soil usage [Skorbiłowicz 2010]

\begin{tabular}{|c|c|c|c|c|}
\hline \multirow[b]{2}{*}{ River } & \multirow{2}{*}{$\begin{array}{c}\text { Afforestation } \\
{[\%]}\end{array}$} & \multicolumn{2}{|c|}{ Agricultural area } & \multirow{2}{*}{$\begin{array}{c}\text { Urban } \\
\text { areas } \\
{[\%]}\end{array}$} \\
\hline & & $\begin{array}{c}\text { Arable } \\
\text { areas [\%] }\end{array}$ & $\begin{array}{c}\text { Pasture and } \\
\text { grasslands [\%] }\end{array}$ & \\
\hline Supraśl & 30 & 39 & 28 & 3 \\
\hline
\end{tabular}

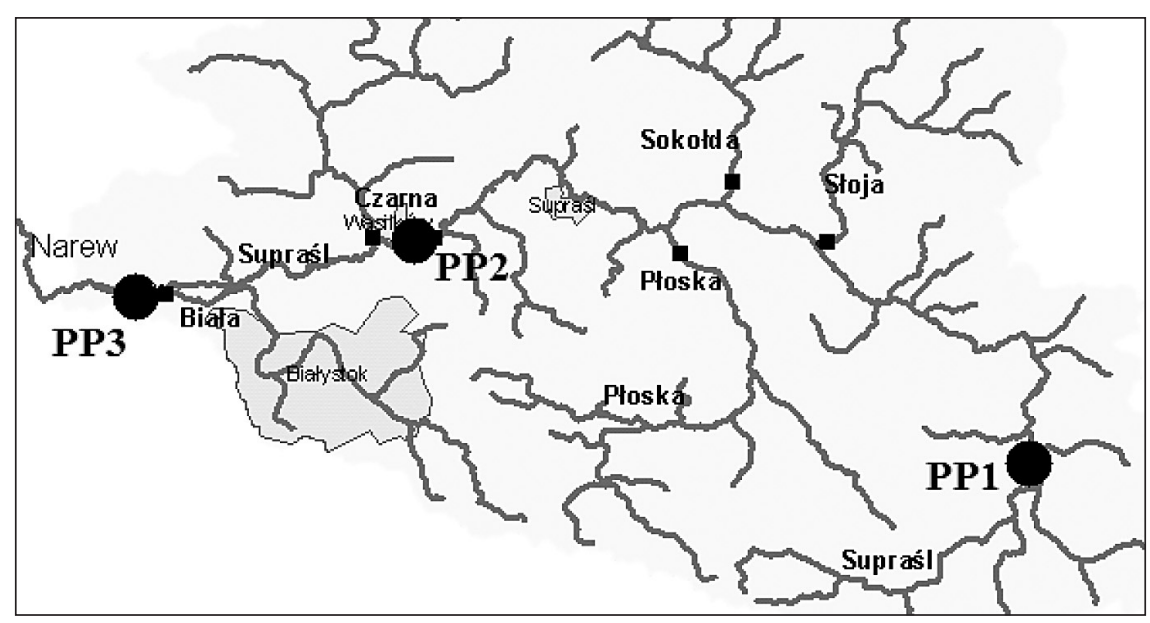

Figure 1. Measurement point localization [Ocena...WIOŚ 2010] 
Table 3. Usage of mineral and organic fertilizers in Podlaskie in 2001-2009 [GUS 2010]

\begin{tabular}{|c|c|c|c|}
\hline \multirow{2}{*}{ Marketing year } & \multicolumn{3}{|c|}{ Fertilizers } \\
\cline { 2 - 4 } & NPK & $\begin{array}{c}\text { Lime } \\
\text { fertilizer }\end{array}$ & $\begin{array}{c}\text { Manure } \\
\text { (NPK) }\end{array}$ \\
\cline { 2 - 4 }$\left[\begin{array}{c}|c| \\
{[\mathrm{kg} / 1 \text { ha agricultural area] }}\end{array}\right.$ \\
\hline 2001 & 78 & 57 & - \\
\hline 2002 & 80 & 59 & - \\
\hline 2003 & 81 & 57 & 62 \\
\hline 2004 & 86 & 61 & 75 \\
\hline 2005 & 87 & 60 & 75 \\
\hline 2006 & 91 & 20 & 78 \\
\hline 2007 & 90 & 11 & 56 \\
\hline 2008 & 94 & 12 & 89 \\
\hline 2009 & 93 & 13 & 67 \\
\hline
\end{tabular}

from 2006 a significant reduction in de-acidification procedures was observed. Soils organic fertilization (manure) was changing from 56 to 89 $\mathrm{kg} \cdot \mathrm{ha}^{-1}$ in period from 2003 to 2009 . The lowest usage of manure for fertilization purposes was noted in 2007 while the highest was in 2008.

According to IMiGW in Białystok, annual precipitation in Podlaskie was ranging from 514 to $715 \mathrm{~mm}$ in period from 2001 to 2009 (Table 4).

Table 4. Annual precipitation in Podlasie [IMiGW Białystok data]

\begin{tabular}{|c|c|}
\hline Year & Annual precipitation [mm] \\
\hline 2001 & 585 \\
\hline 2002 & 514 \\
\hline 2003 & 556 \\
\hline 2004 & 630 \\
\hline 2005 & 560 \\
\hline 2006 & 610 \\
\hline 2007 & 616 \\
\hline 2008 & 613 \\
\hline 2009 & 715 \\
\hline
\end{tabular}

\section{RESULTS AND DISSCUSSION}

Analysis of mineral compounds specific loads eluted from catchment is very difficult due to the fact that the amount of leachable components depends on the influence of natural factors, climate, physiographic characteristics, type and structure of land usage and anthropogenic factors such as the amount of used fertilizers and water and sewage management in the catchment [Sojka 2009].
In most cases, anthropogenic factors are increasing specific loads of components outflowing from the catchment area. On the other hand, natural factors can increase or reduce specific loads of each component.

The highest average annual specific loads of examined components in Supraśl catchment are eluted from Dzikie micro-catchment (Table 5), while the smallest form micro-catchment Gródek. This phenomena is primarily dictated by catchment size.

Table 5. Average specific load in measurement points

\begin{tabular}{|c|c|c|c|c|}
\hline Component & Unit & Gródek & Nowodworce & Dzikie \\
\hline $\mathrm{N}-\mathrm{NH}_{4}{ }^{+}$ & \multirow{8}{*}{$\mathrm{kg} \cdot \mathrm{ha}^{-1} \cdot \mathrm{year}^{-1}$} & 0.07 & 0.11 & 0.30 \\
\hline $\mathrm{N}-\mathrm{NO}_{3}^{-}$ & & 0.47 & 1.30 & 3.15 \\
\hline $\mathrm{P}-\mathrm{PO}_{4}{ }^{3-}$ & & 0.12 & 0.24 & 0.60 \\
\hline$P_{\text {og }}$ & & 0.18 & 0.49 & 1.05 \\
\hline $\mathrm{S}-\mathrm{SO}_{4}{ }^{2-}$ & & 6.20 & 23.67 & 52.78 \\
\hline $\mathrm{Cl}^{-}$ & & 2.59 & 9.24 & 42.55 \\
\hline $\mathrm{Ca}^{2+}$ & & 15.08 & 80.43 & 120.47 \\
\hline $\mathrm{Mg}^{2+}$ & & 1.90 & 11.73 & 18.13 \\
\hline
\end{tabular}

$\mathrm{N}-\mathrm{NH}_{4}{ }^{+}$specific load values (Figure 2) ranged from 0.11 to $0.33 \mathrm{~kg} \mathrm{NH}_{4}^{+} \mathrm{ha}^{-1}$.year ${ }^{-1}$. The lowest load value of this component was observed in 2007, while the highest in 2006. Average annual load values did not differ by more than $0.04 \mathrm{~kg} \mathrm{~N}-\mathrm{NH}_{4}^{+}$ $\mathrm{ha}^{-1} \cdot$ year $^{-1}$. The only exception was noted in differences obtained at maximum load, which was observed in 2006. Similar $\mathrm{N}_{-} \mathrm{NH}_{4}^{+}$loads were observed by Marchlewska [1991]. $\mathrm{N}^{-\mathrm{NH}_{4}+}$ load values obtained by Marchlewska ranged from 0.051 to $2.094{\mathrm{~kg} \mathrm{~N}-\mathrm{NH}_{4}^{+}}^{+} \mathrm{ha}^{-1}$.year ${ }^{-1}$, but it must be noted that the highest $\mathrm{N}^{+} \mathrm{NH}_{4}^{+}$load particularly depended on the catchment area. Average annual $\mathrm{P}_{-} \mathrm{PO}_{4}^{3-}$ specific loads (Figure 3) ranged from 0.21 to $0.51 \mathrm{~kg}$

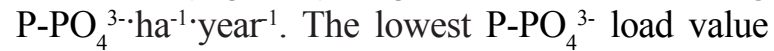
was observed in 2009 while the highest in 2001. Similar $\mathrm{P}_{-} \mathrm{PO}_{4}^{3-}$ load values were achieved by Krajewska and Bogdanowicz [2009] in research carried out in Reda, Zagórska Struga, Płutnica and Gizdepka catchments. Load obtained by them were ranging from 0.17 to $0.45 \mathrm{~kg} \mathrm{P}^{-\mathrm{PO}_{4}^{3--} \mathrm{ha}^{-1} \text { year }}$.

The performed statistical analysis showed a correlation between $\mathrm{N}-\mathrm{NH}_{4}{ }^{+}$specific load and mineral fertilization level in Supraśl catchment.

Average annual $\mathrm{N}^{-\mathrm{NO}_{3}}{ }_{3}^{-}$loads values (Figure

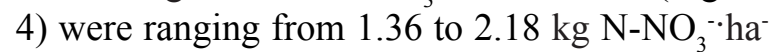
${ }^{1}$ year ${ }^{-1}$. The lowest load value of this component was observed in 2009, while the highest in 2002. Average annual load values did not differ by more than $0.50 \mathrm{~kg} \mathrm{~N}^{-\mathrm{NO}_{3}}{ }^{-} \mathrm{ha}^{-1} \cdot$ year $^{-1}$. Higher range of 


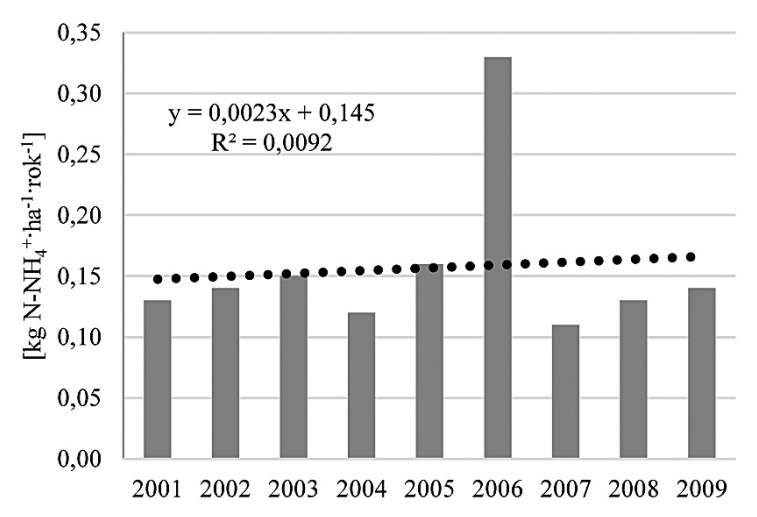

Figure 2. Average annual loads of $\mathrm{N}-\mathrm{NH}_{4}^{+}$

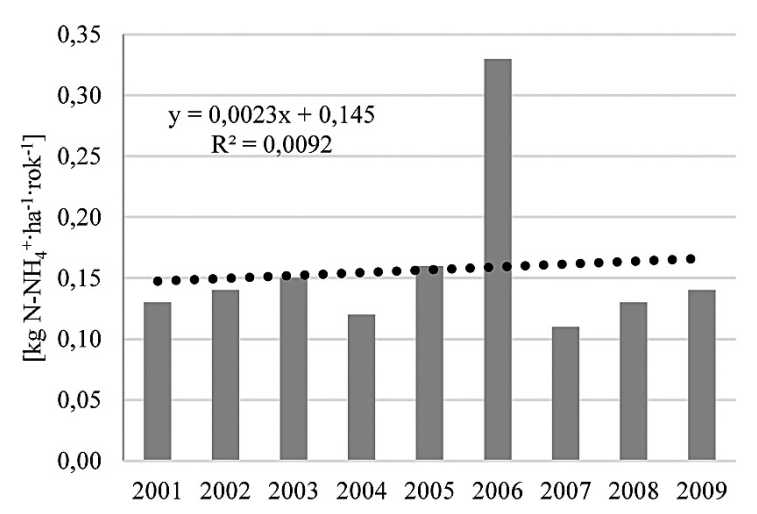

Figure 3. Average annual loads of $\mathrm{P}_{-} \mathrm{PO}_{4}^{3-}$

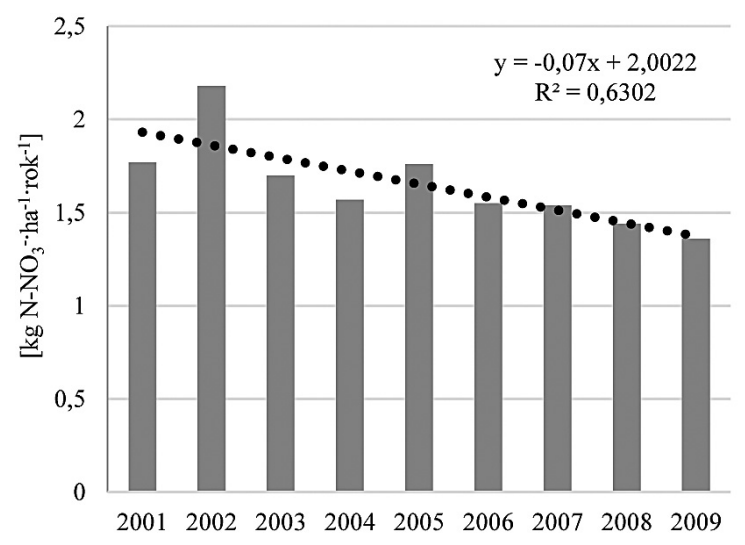

Figure 4. Average annual loads of $\mathrm{N}^{-\mathrm{NO}_{3}}{ }^{-}$

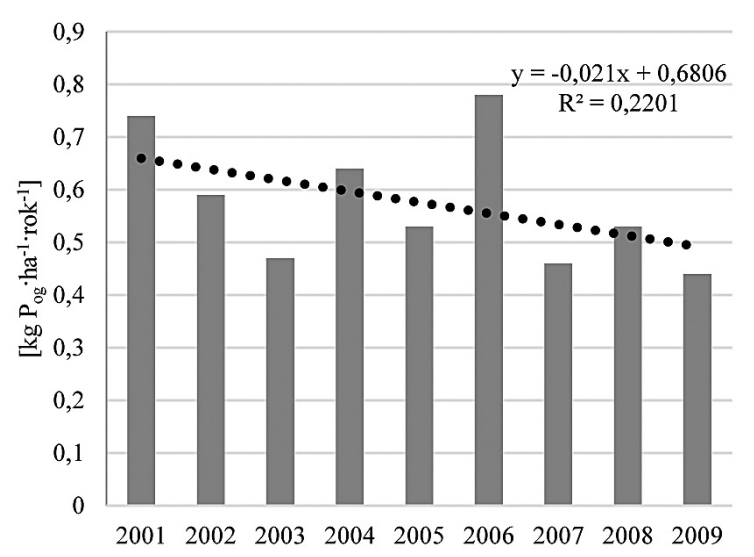

Figure 5. Average annual loads of total phosphorus

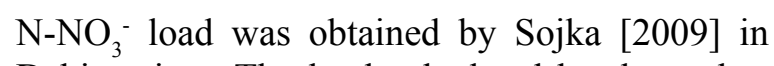
Dębina river. The load calculated by the author

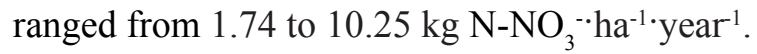

Average annual total phosphorus loads (Figure 5) were changing in a range from 0.44 to $0.78 \mathrm{~kg}$ $\mathrm{P} \cdot \mathrm{ha}^{-1} \cdot \mathrm{rok}^{-1}$. The lowest load of these components was observed in 2009 and the highest in 2006. Total phosphorus load changes trend, in research period, was similar to changes of phosphates load. Similar total phosphorus loads were observed by Grabińska [2007]. Specific load values calculated by the author ranged from 0.17 to $1.27 \mathrm{~kg} \mathrm{P} \cdot \mathrm{ha}^{-1}$ year $^{-1}$. Those results were obtained for mixed forested and agricultural catchment in the upper Narew.

Statistical analysis performed in this study has shown a correlation between total phosphorus specific load and mineral and organic fertilization level in Supraśl catchment.

Average annual S- $\mathrm{SO}_{4}^{2-}$ loads (Figure 6), in the research period, ranged from 24.75 to $33.71 \mathrm{~kg}$ $\mathrm{S}^{-} \mathrm{SO}_{4}^{2-\cdot \text { ha }^{-1} \text { year }}{ }^{-1}$. The lowest specific load was observed in 2007 and the highest in 2004. Similar load range of this component was achieved by Jekatierynczuk-Rudczyk et al. [2006]. S-SO ${ }_{4}^{2-}$ load values obtained by the authors changed from 5,44 do 35,03 $\mathrm{kg} \mathrm{S}^{-\mathrm{SO}_{4}}{ }_{4}^{-\cdot}$ ha $^{-1}$.year ${ }^{-1}$ and were observed in Horodnianka catchment. Horodnianka drains agricultural areas near Białystok.

Statistical models obtained in this study point to correlations between $\mathrm{S}_{-} \mathrm{SO}_{4}{ }^{2-}$ specific load and organic fertilization and $\mathrm{S}_{-} \mathrm{SO}_{4}{ }^{2-}$ specific load and annual precipitation.

Average annual chlorides load was ranging from 14,58 to $26,80 \mathrm{~kg} \mathrm{Cl}^{-} \mathrm{ha}^{-1}$ year ${ }^{-1}$. The lowest specific load value of this component was observed in 2001 while the highest in 2002. Obtained chlorides loads values are similar to those that were observed by Ostrowski i Bogdał in agricultural micro-catchment Wronowiec [2006]. Those loads were ranging from 8,41 to $14,74 \mathrm{~kg}$ $\mathrm{Cl}^{-\bullet} \mathrm{ha}^{-1}$ year ${ }^{-1}$. Numerical calculations point to a correlation between $\mathrm{Cl}^{-}$specific load and mineral fertilization level.

Calcium average loads values were changing from 68,2 do 77,1 $\mathrm{kg} \mathrm{Ca}^{2+} \cdot \mathrm{ha}^{-1}$ year ${ }^{-1}$ during research period (Figure 8). The lowest value of this load was observed in 2008 and the highest in 2001. Similar $\mathrm{Ca}^{2+}$ loads values were obtained by Sidoruk and Skwierawski [2006] during studies carried out in waters outflowing from forested areas to Bukwład lake. Average $\mathrm{Ca}^{2+}$ load values obtained by the authors was equal to $63,6 \mathrm{~kg}$ $\mathrm{Ca}^{2+} \cdot$ ha $^{-1} \cdot$ year $^{-1}$. 
The highest specific load of $\mathrm{Mg}^{2+}$ was observed in 2001 while the lowest in 2008. Those values were equal respectively 12.29 and $9.57 \mathrm{~kg}$ $\mathrm{Mg}^{2+} \cdot$ ha $^{-1}$.year ${ }^{-1}$. Alike case of $\mathrm{Ca}^{2+}$ loads, $\mathrm{Mg}^{2+}$ loads values were decreasing in each year of studies. This phenomenon is probably caused by lime and magnesium fertilizers used in that area. In most cases, lime fertilization is related to simultaneous calcium and magnesium usage. This procedure allows to obtain higher crops. Similar $\mathrm{Mg}^{2+}$ loads were obtained by Cymes and Szymczak [2005] in waters flowing through arable areas $\left(15.4 \mathrm{~kg} \mathrm{Mg}^{2+} \cdot \mathrm{ha}^{-1} \cdot \mathrm{year}^{-1}\right)$ and grasslands $(13.4 \mathrm{~kg}$ $\mathrm{Mg}^{2+} \cdot \mathrm{ha}^{-1}$ year $\left.{ }^{-1}\right)$ on heavy soils.

Statistical test performed in this study pointed out a correlation between lime and organic fertilization and $\mathrm{Ca}^{2+}$ and $\mathrm{Mg}^{2+}$ specific loads.

A dependence of $\mathrm{S}_{-} \mathrm{SO}_{4}^{2-}, \mathrm{Ca}^{2+}$ and $\mathrm{Mg}^{2+}$ specific loads from usage of manure fertilizer in micro-catchment area of Gródek catchment was discovered with Pearson correlation coefficients equal respectively $\mathrm{r}=0.76, \mathrm{r}=0.83$ and $\mathrm{r}=0.79$. This phenomena could be correlated with the usage of manure fertilization in this area but not with soil types in that catchment. Many studies shown that soils in Gródek micro-catchment are of post bog origin, which are not rich in calcium and magnesium.

From micro-catchment Nowodworce outflows $\mathrm{N}-\mathrm{NH}_{4}^{+}, \mathrm{P}_{\mathrm{og}}, \mathrm{Cl}^{-}, \mathrm{Ca}^{2+}$ i $\mathrm{Mg}^{2+}$ specific load positively correlated with the usage of NPK fertilization with coefficients equal respectively $\mathrm{r}=0.87$, $\mathrm{r}=0.79, \mathrm{r}=0.74, \mathrm{r}=0.51$ and $\mathrm{r}=0.66$. The loads of total phosphorus and $\mathrm{P}_{-} \mathrm{PO}_{4}{ }^{3-}$ are positively correlated with organic fertilization value with coefficients equal respectively $\mathrm{r}=0.54$ and $\mathrm{r}=0.61$.

Lime fertilization value was positively correlated with $\mathrm{Ca}^{2+}$ and $\mathrm{Mg}^{2+}(\mathrm{r}=0.79$ and $\mathrm{r}=0.85)$ load from surface run-offs in Dzikie micro-catchment. In this area, as shown by Skorbiłowicz [2010a], intensively fertilized, acidic light soils are present which are probably the cause of high macroelements' concentration in waters from drainages that flow to many ditches located in this area. This phenomenon was also indicated by Terelaka et al. [1999], Koc et al. [1997] and Sapek [1995] in their research carried out in other catchments. Recent studies carried out by Skorbiłowicz [2010b] also confirm those observation in Supraśl catchment.

No positive Pearson and Spearman correlation coefficients were noted between precipitation (Table 4) and specific load of each com-

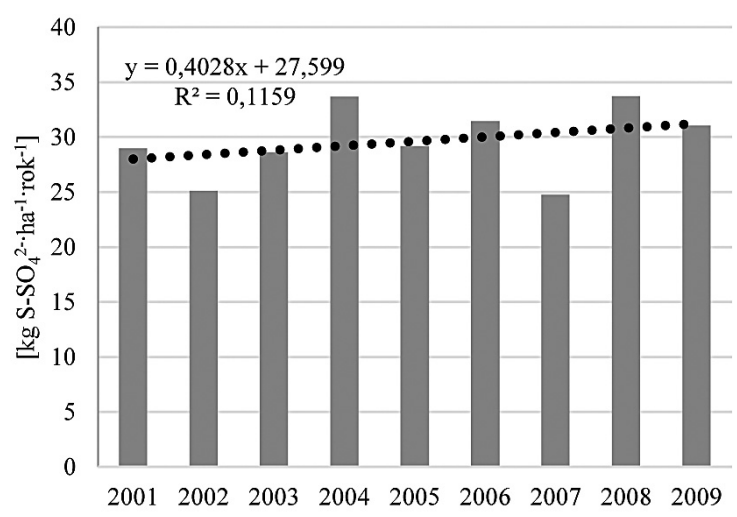

Figure 6. Average annual loads of $\mathrm{S}^{-\mathrm{SO}_{4}{ }^{2-}}$

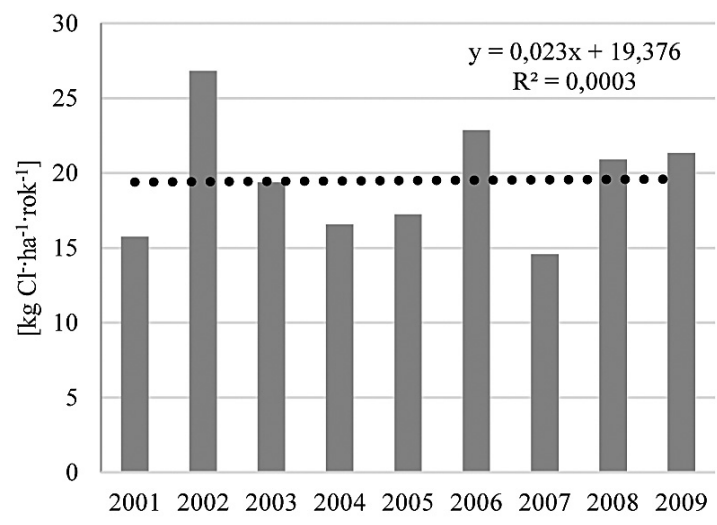

Figure 7. Average annual loads of $\mathrm{Cl}^{-}$

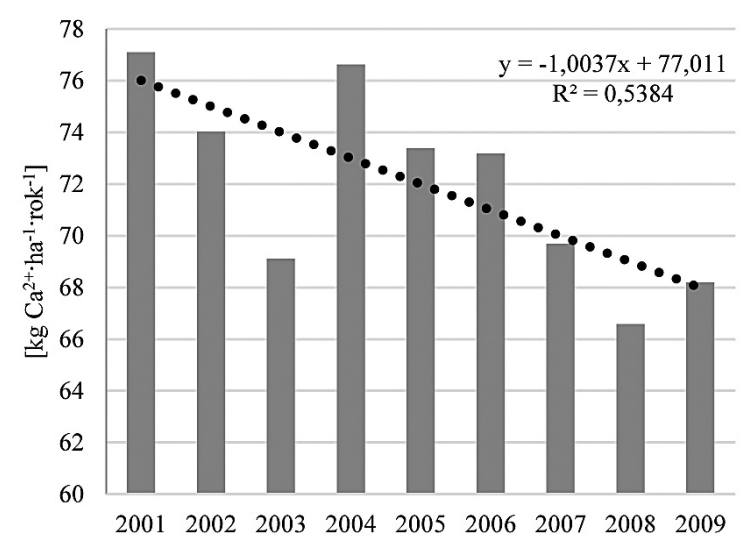

Figure 8. Average annual loads of $\mathrm{Ca}^{2+}$

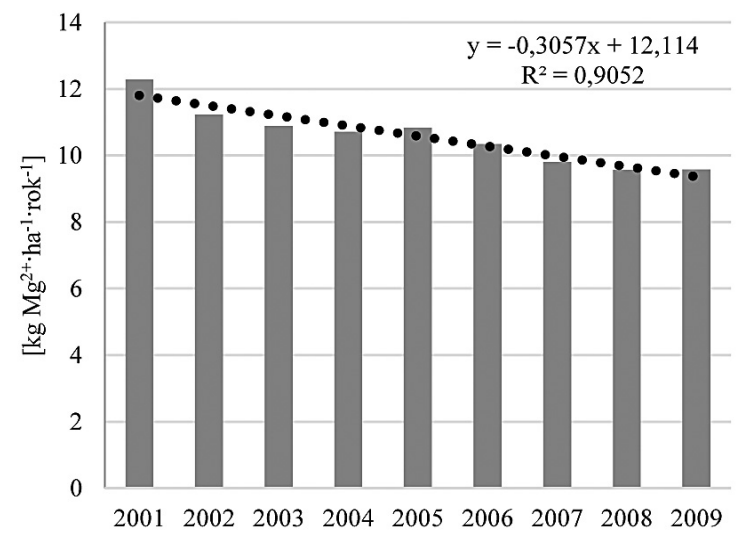

Figure 9. Average annual loads of $\mathrm{Mg}^{2+}$ 
ponent, except sulfates $(\mathrm{r}=0.50)$. Supraśl catchment is characterized by $30 \%$ afforestation (Table 2 ) and forests have strong a retention impact on natural waters, hence there is probably a lack of clear relationships between the amount of precipitation and specific loads in the studied catchment. Artificial neural network sensitivity analysis performed by Skorbiłowicz [2010b] showed that network was most sensitive to location of a measuring point at Supraśl, and less sensitive to the amount of precipitation in the catchment. Neither did Skorbiłowicz obtain a reliable relationship between component concentration in waters and their average specific loads outflowing from catchment.

\section{CONCLUSIONS}

1. Specific loads of $\mathrm{N}-\mathrm{NO}_{3}{ }^{-}, \mathrm{P}_{-} \mathrm{PO}_{4}{ }^{3-}, \mathrm{P}_{\mathrm{og}}, \mathrm{Ca}^{2+}$ and $\mathrm{Mg}^{2+}$ outflowing form Supraśl catchment were characterized by decreasing trend and specific loads of $\mathrm{N}^{-\mathrm{NH}_{4}}{ }^{+}, \mathrm{S}_{-} \mathrm{SO}_{4}{ }^{2-}$ and $\mathrm{Cl}^{-}$were characterized by increasing trend in the period from 2001 to 2009 .

2. Statistical analysis showed dependence of $\mathrm{S}^{-} \mathrm{SO}_{4}{ }_{4}^{2-}, \mathrm{Ca}^{2+}$ and $\mathrm{Mg}^{2+}$ specific loads on manure fertilization value in Gródek micro-catchment.

3. From Nowodworce micro-catchment outflows positively correlated specific loads of $\mathrm{NH}_{4}^{+}$, $\mathrm{P}_{\text {og }}, \mathrm{Cl}-\mathrm{Ca}^{2+}$ and $\mathrm{Mg}^{2+}$ with NPK fertilization value. Total phosphorus and $\mathrm{P}^{\mathrm{og}} \mathrm{PO}_{4}{ }^{3-}$ loads outflowing form micro-catchment were correlated with organic fertilization value.

4. $\mathrm{Ca}^{2+}$ and $\mathrm{Mg}^{2+}$ load were positively correlated with lime fertilization value in micro-catchment Dzikie.

5. One statistically significant Pearson correlation was observed between precipitation and sulfates load.

\section{REFERENCES}

1. Cymes I., Szymczyk S. 2005. Wpływ sposobu użytkowania terenu, melioracji i czynników naturalnych na stężenie sodu, wapnia i magnezu w wodach gruntowych i ich odpływ siecią drenarską z gleb ciężkich. Inżynieria Ekologiczna, 13, 44-49.

2. Grabińska B., Koc J., Skwierawski A., SobczyńskaWójcik K., Rafałowska M. 2005. Stężenia i odpływ fosforu ogólnego z wodami rzecznymi ze zlewni zróżnicowanym użytkowaniu. Inżynieria Ekologiczna, 13, 87-92.
3. Jekatierynczuk-Rudczyk E., Zieliński P., Górniak A. 2006. Stopień degradacji rzeki wiejskiej w bezpośrednim sąsiedztwie Białegostoku. WodaŚrodowisko-Obszary Wiejskie, 2(18), 143-153.

4. Koc J., Procyk Z., Szymczyk S. 1997. Czynniki kształtujące jakość wód powierzchniowych obszarów wiejskich. Materiały Seminaryjne IMUZ 39, 222-229.

5. KrajewskaZ., BogdanowiczR. 2009. Zróżnicowanie wielkości eksportu substancji biogennych w zlewisku Zatoki Puckiej. [In:] Janowski A.T., Absalon D., Machowski R., Ruman M. (Eds.) Przeobrażenia stosunków wodnych w warunkach zmieniającego się środowiska. Wydział Nauk o Ziemi Uniwersytetu Śląskiego, Sosnowiec, 177-186.

6. Marchlewska B. 1991. Obciążenie związkami biogennymi zlewni rzek w województwie legnickim, Ochrona Środowiska, 2(43), 19-21.

7. Ostrowski K. Bogdał A. 2006. Loads of selected chemical components delivered by percipitation and flowing away from Wronowiec microcatchment. Acta Scientiarum Polonorum, 5(2), 37-46.

8. Sapek B. 1995. Wymywanie azotanów oraz zakwaszanie gleby i wód gruntowych w aspekcie działalności rolniczej. Materiały Informacyjne IMUZ, Falenty, 30, 1-31.

9. Sidoruk M., Skwierawski A. 2006. Wpływ użytkowania zlewni na ładunek wapnia, sodu, potasu i magnezu w wodach dopływających do jeziora Bukwład. Ecological Chemistry and Engineering, S2(13), 337-343.

10. Skorbiłowicz M. 2010(a). The concentrations of macroelements, zinc and iron ions in waters of the upper Narew basin, NE Poland. Polish Journal of Environmental Studies, 2(19), 397-405.

11. Skorbiłowicz M. 2010(b). Czynniki i procesy kształtujące obieg składników mineralnych w wodach rzecznych zlewni górnej Narwi. Oficyna Wydawnicza Politechniki Białostockiej, Białystok.

12. Sojka M. 2009. Ocena ładunków związków biogennych wymywanych ze zlewni cieku Dębina. Środkowo-Pomorskie Towarzystwo Naukowe Ochrony Środowiska, 11, 1225-1234.

13. Terelak H., Motowicka-Terelak T., Sadurski W. 1999. Wymywanie składników chemicznych Z gleb gruntów ornych do wód drenarskich. [In:] Ochrona zasobów i jakości wód powierzchniowych i podziemnych. Wyd. Ekonomia i Środowisko, Białystok.

14. Urząd Statystyczny 2010. Ludność, ruch naturalny, migracje w województwie podlaskim w 2010 r., Białystok.

15. Wojewódzki Inspektorat Ochrony Środowiska w Białymstoku 2011. Ocena stanu czystości wód w zlewni rzeki Supraśl w 2010 roku. 